\title{
Eunice Katunda e seu Quinteto Schoenberg: uma homenagem ao criador do dodecafonismo
}

\author{
Marisa Milan Candido \\ Universidade de São Paulo \\ marisamilan@usp.br \\ Eliana Monteiro da Silva \\ Universidade de São Paulo \\ ms.eliana@usp.br
}

\begin{abstract}
Resumo: Eunice Katunda (1915-1990) foi uma importante musicista brasileira do século XX. Viveu e atuou de maneira intensa no campo musical por quase todo o século, realizando atividades como pianista, compositora, regente, pesquisadora, professora, crítica, entre outros. Foi responsável tanto pela estreia e difusão de inúmeras obras brasileiras e estrangeiras desconhecidas no meio musical de sua época, como pela criação de peças a partir de modernas técnicas de composição. Neste artigo trataremos do uso feito pela compositora da técnica dodecafônica criada pelo compositor austríaco-estadunidense Arnold Schoenberg (1874-1951), a quem ela homenageou em seu Quinteto Schoenberg. Através de análise musical, mostraremos, entre outros procedimentos, como a compositora utilizou na serie inicial de sua obra o hexacorde inversionalmente simétrico catalogado por Allen Forte como 6-20, usado por Schoenberg em seu quinteto Ode to Napoleon Buonaparte Op. 41. Paralelamente, a musicista inseriu melodias de inspiração folclórica nacional, a fim de dar à composição um caráter humanista e crítico do período em que foi criada.
\end{abstract}

Palavras-chave: Quinteto Schoenberg, Eunice Katunda, Arnold Schoenberg, Dodecafonismo, Compositora Brasileira.

\section{Eunice Katunda's Quinteto Schoenberg: a tribute to the creator of dodecaphonism}

Abstract: Eunice Katunda (1915-1990) was an important $20^{\text {th }}$ century Brazilian musician. She lived and performed intensely in the musical field for almost the entire century, executing activities as a pianist, composer, conductor, researcher, teacher, critic, among others. She was responsible for both the premiere and dissemination of numerous Brazilian and foreign pieces of work until unknown in the musical environment up to that time, as well as for the creation of music using modern composition techniques. In this article, we will discuss the composer's use of the dodecaphonic technique created by the AustrianAmerican composer Arnold Schoenberg (1874-1951), whom she paid tribute to in ger Quinteto Schoenberg. Through musical analysis, we will show, among other procedures, how the composer used in the initial series of her work the inversionally symmetric hexachord cataloged by Allen Forte as 6-20, used by Schoenberg in his own quintet Ode to Napoleon Bonaparte Op 41. In a parallel movement, the musician inserted national folk-inspired melodies in order to give the composition a humanist and critical character of the period in which was created.

Keywords: Quinteto Schoenberg, Eunice Katunda, Arnold Schoenberg, Dodecaphonism, Brazilian Woman Composer.

\section{Introdução}

A compositora brasileira Eunice Katunda nasceu no Rio de Janeiro, em 14 de março de 1915, e faleceu em São José dos Campos, em 3 de agosto de 1990. Foi uma importante musicista no sentido real do termo, pois sua atuação se deu em diversas vertentes do 
campo musical - tais como pianista, compositora, regente, pesquisadora, professora, crítica, entre outros.

Seu desempenho como intérprete e compositora, especialmente na década de 1940, foi responsável tanto pela estreia e difusão de inúmeras obras brasileiras e estrangeiras desconhecidas no meio musical da época, como pela criação de peças a partir de modernas técnicas de composição. Entre as técnicas por ela utilizadas, trataremos neste artigo do dodecafonismo criado pelo compositor austríaco-estadunidense Arnold Schoenberg (1874-1951), homenageado por Eunice Katunda em seu Quinteto Schoenberg.

Sua extensa trajetória musical - Eunice compôs por quase toda a sua vida - pode ser dividida em quatro fases composicionais: Fase de Formação (até 1945), Fase Música Viva (1946-1950), Fase Nacionalista (1951-1968) e Fase Final (Após 1968). Esta divisão está diretamente relacionada à sua trajetória pessoal, ou seja, aos professores de piano e matérias teórico-musicais que influenciaram sua produção criativa, às cidades em que morou e vivenciou ambientes culturais específicos, assim como pelas suas preferências estéticas, artísticas e políticas (ZANI; SILVA; CANDIDO, 2019, p. 117-126).

O Quinteto Schoenberg aqui analisado pertence à sua segunda fase, Música Viva, em que morou no Rio de Janeiro e esteve vinculada ao movimento e grupo de compositores que levaram este nome sob a liderança e orientação do compositor, flautista e professor alemão Hans-Joachim Koellreutter. Esta fase foi marcada, principalmente, pela experimentação feita pelo grupo em geral e pela compositora em particular da técnica de escrever com os doze sons da escala cromática, denominada dodecafônica, assim como pela militância estética e política efetuada por vários(as) integrantes do Música Viva, incluindo Eunice Katunda (Ibid.).

A escolha da obra Ode to Napoleon Buonaparte Op. 41 como referência para a criação de seu Quinteto - através, principalmente, da serie dodecafônica com que a compositora inicia esta peça, baseada em hexacorde formulado por Schoenberg $^{1}$ - atesta seu interesse em dar um caráter humanista e crítico a uma composição de cunho formalista, como era vista a escrita com doze sons. A obra Ode to Napoleon Buonaparte fora composta por Schoenberg em 1942 com base no poema homônimo de Lord Byron

\footnotetext{
${ }^{1}$ Como citado no resumo, o referido hexacorde é catalogado como 6-20 (0 1458 9) na lista de Allen Forte e tem a peculiaridade de ser inversionalmente simétrico, ou seja, de igual leitura em termos de intervalos utilizados tanto da esquerda para direita como vice-versa (Cf.: STRAUS, 2005, p. 85, 264).
} 
(1814), em que o autor ironicamente se referia à derrota de Napoleão ao invadir a Rússia nas chamadas guerras napoleônicas (SHAW; AUNER, 2010, p. 11). Outros compositores se referiram ao Op. 41 de Schoenberg com semelhante intuito, como foi o caso do italiano Luigi Nono, com quem Eunice Katunda trocou ideias e até materiais composicionais em torno a este tema (IDDON, 2013, p. 43-45) ${ }^{2}$.

Assim como Schoenberg utilizara um poema de Byron para dar dramaticidade a uma obra baseada numa técnica cerebral e auditivamente pouco compreensível como a dodecafônica, Eunice Katunda inseriu melodias e ritmos de inspiração folclórica nacional em seu Quinteto dedicado ao compositor. Com esse procedimento ela se aproximou da missão atribuída ao criador do dodecafonismo por Walter Bailey (apud SHAW; AUNER, 2010, p. 12): vencer "os desafios de reconciliar 'Coração e Cérebro na Música". 3

\section{Eunice Katunda, o grupo Música Viva e o dodecafonismo}

Eunice Katunda iniciou seus estudos de piano e teoria musical ainda criança. Ao longo de seu percurso como aluna passou pela orientação de diferentes professores(as), como Branca Bilhar, Oscar Guanabarino, Furio Franceschini, Marietta Lion e Camargo Guarnieri. Por esta razão a primeira fase composicional de Eunice Katunda foi denominada neste trabalho como Fase de Formação, e se refere ao seu desenvolvimento como pianista e ao início de sua carreira como compositora até 1945.

Observa-se que o repertório relativo a esta fase abrange uma lista de compositores comuns à formação de pianistas, tais como Bach, Mozart, Beethoven, Schumann, Chopin, entre outros. No entanto, verifica-se que desde suas primeiras apresentações em público ela foi estimulada a tocar também peças brasileiras, como as de sua professora Branca Bilhar, do compositor Heitor Villa-Lobos e de outros(as) autores(as) vinculados à estética nacionalista.

Já a segunda fase composicional de Eunice, denominada Música Viva, refere-se ao período em que ela esteve diretamente ligada ao movimento e ao grupo de compositores de mesmo nome, entre 1946 e 1950. Seu contato com o Música Viva se deu através do

\footnotetext{
${ }^{2}$ Luigi Nono teria se inspirado no Op. 41 de Schoenberg para compor a obra Variazioni canoniche sulla serie dell'op. 41 di Arnold Schoenberg, para orquestra, em 1950 (IDDON, 2013, p. 37-38).

${ }^{3}$ [Schoenberg's lifelong engagement with] the challenges of reconciling the "Heart and Brain in Music".
} 
principal signatário do movimento, Hans-Joachim Koellreutter, com quem teve aulas de harmonia e composição.

O movimento - que passou por três momentos distintos, sendo os dois últimos destacados pela criação do grupo de compositores e pela promoção de modernas técnicas composicionais, como o dodecafonismo - promoveu várias atividades em prol da divulgação da música atonal e/ou de composições pouco conhecidas no Brasil. Como uma de suas principais representantes, Eunice Katunda assinou uma carta de princípios do grupo intitulada Manifesto 1946, foi redatora dos boletins Música Viva, além de pianista do programa radiofônico e de eventos como recitais solos e coletivos.

Em 1948 fez uma viagem à Europa com Koellreutter e outros colegas para participar do Curso Internacional de Regência, realizado pela Bienal de Veneza e ministrado pelo maestro e compositor alemão Hermann Scherchen ${ }^{4}$. Esta viagem, inicialmente prevista para dois meses, foi prolongada por quase um ano, proporcionandolhe, além do estudo, muitas realizações como instrumentista e compositora.

Foi durante a viagem que Eunice Katunda aprofundou seu conhecimento acerca da técnica dodecafônica, participando não só de estudos coletivos realizados pelo grupo, como de um curso ministrado por Koellreutter em Milão. (KATER, 2020, p. 150). Além disso, seu ciclo de peças Cantos à morte, baseado na escrita schoenberguiana dos doze sons, foi estreado mundialmente sob a regência de Scherchen na Rádio Difusão Zurique. Já sua transcrição para piano, nomeada como Quatro epígrafes, foi estreada no I Congresso de Música Dodecafônica, em Lugano (Suíça).

A atuação de Eunice Katunda como intérprete de obras com esta linguagem corroborou sua habilidade no trato desse material - series ordenadas de doze sons variadas através de inversão, retrogradação, inversão da retrogradação, transposição, etc. A musicista foi indicada intérprete oficial do grupo no I Congresso Internacional de Compositores Dodecafônicos, realizado em Lugano, em que apresentou, entre outras, a obra Ludus tonalis (1942) de Paul Hindemith em primeira audição. O jornal L'Humanita destacou que ela demonstrou ser uma pianista segura e que seu equilíbrio the permitiu um desempenho verdadeiramente notável ${ }^{5}$ (L.F., 1948, apud KATUNDA, c.1925-c.1970) ${ }^{6}$.

\footnotetext{
${ }^{4}$ De acordo com Kater (2001, p. 45), Scherchen criou a expressão "Música Viva" para inaugurar um movimento e um periódico musical de mesmo nome que foi editado em Bruxelas entre 1933 e 1936.

${ }^{5}$ A crítica suíça citou a peça de Hindemith como o novo "Cravo bem temperado", de Bach (L.F., 1948).

${ }^{6}$ Todas as matérias de jornais a respeito da atuação e Eunice Katunda como pianista e compositora aqui citadas foram retiradas do Álbum de recortes de jornais constante de seu acervo pessoal. Constam deste
} 
Entre compositores e compositoras com quem se relacionou destaca-se a amizade travada com os italianos Luigi Nono e Bruno Maderna. Os três amigos empreenderam maratonas de estudos de contraponto, além de discutir literatura, política e filosofia.

\begin{abstract}
Katunda era influente politicamente: era comunista e, embora Nono e Maderna já tivessem inclinações esquerdistas, o exemplo de Katunda era um estímulo a mais para que eles integrassem o Partito Comunista Italiano (Partido Comunista Italiano) em 1952. Musicalmente, entretanto, ela não era menos significante. Apresentou aos dois italianos a obra de Federico García Lorca e "os ritmos do Mato Grosso [um dos estados do Brasil], o que em certos aspectos antecipou os ensinamentos de Varèse (IDDON, 2013, p. 43) ${ }^{7}$.
\end{abstract}

Sobre esta amizade a compositora escreveria:

Conheci Bruno Maderna, Luigi Nono, Scherchen, Dallapiccola, Ungaretti. Aliás, o Maderna foi o sujeito mais completamente músico que conheci. Eu, ele e Nono formávamos um grupo que trabalhava regularmente, desde serialismo até a "Arte da Fuga". Scherchen nos distinguia de maneira especial. Nos chamava sempre para qualquer tarefa, ensaio, preparação de naipes... e lá estávamos nós três, juntos! (KATUNDA, apud KATER, 2020, p. 54-55).

Como foi dito anteriormente, Nono comporia a obra Variazioni Canoniche sulla serie dell'op. 41 di Arnold Schoenberg em 1950, sobre a mesma obra utilizada por Eunice no Quinteto Schoenberg, a Ode to Napoleon Buonaparte Op. 41. Assim como a compositora, um dos aspectos que mais chamaram a atenção do compositor italiano foi a simetria entre os dois hexacordes da serie original usada por Schoenberg na obra citada, além da inspiração num texto que aludia à opressão exercida por um imperador como Napoleão - que Schoenberg relacionava aos horrores da $2^{\mathrm{a}}$ Guerra Mundial.

Eunice Katunda ainda empregou o mesmo conjunto inversionalmente simétrico da Ode to Napoleon em ambos os hexacordes de sua serie inicial, catalogado por Allen Forte como 6-20 (0 14458 9), enquanto Nono se ateve mais à serialização dos ritmos em suas

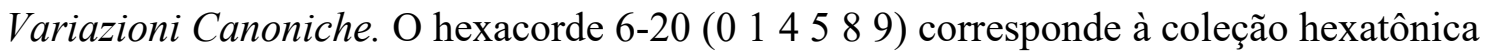
formada por intervalos de $2 \mathrm{~m}$ separados por uma $3 \mathrm{~m}$, e a combinação de seus elementos

álbum, desde fotos, até críticas publicadas em jornais, sendo que nem todas apresentam nomes de autores(as) e datas precisas. Sendo assim, optou-se por citar o álbum como referência e colocar como data o intervalo do que parece ter sido o primeiro documento coletado pela compositora (1925) e o último (1970).

${ }^{7}$ Katunda was influential politically: she was a communist and, though both Nono and Maderna had already strong leftist inclinations, the example of Katunda was a further spur for them to join to the Partito Comunista Italiano (the Italian Communist Party) in 1952. Musically, however, she was no less significant. She introduced the two Italians to the work of Federico Garcia Lorca and to "the rhythms of the Mato Grosso (one of Brazil's western states), which anticipated in certain respects what Varèse taught". 
pode gerar tríades maiores, como o subconjunto (1 58 ), menores, como o (1 48 ), ou aumentadas, como o (0 4 8).

Figura 1: Hexacorde 6-20 (0 1458 9) usado por Schoenberg em Ode to Napoleon (c. 62) na parte do violino I e violino II.

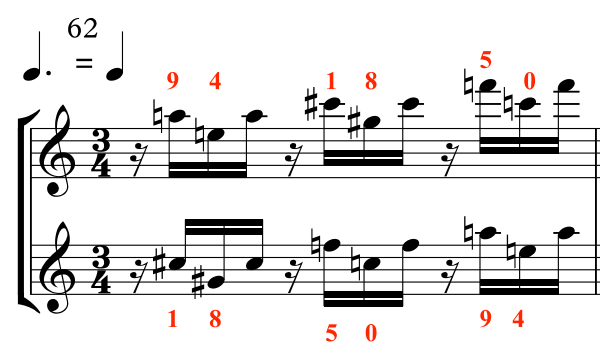

Fonte - Elaboração das autoras.

Figura 2: Hexacorde 6-20 (0 1458 9) usado por Eunice Katunda em Quinteto Schoenberg (c. 1-2), mapeado na parte do piano e do clarinete baixo.

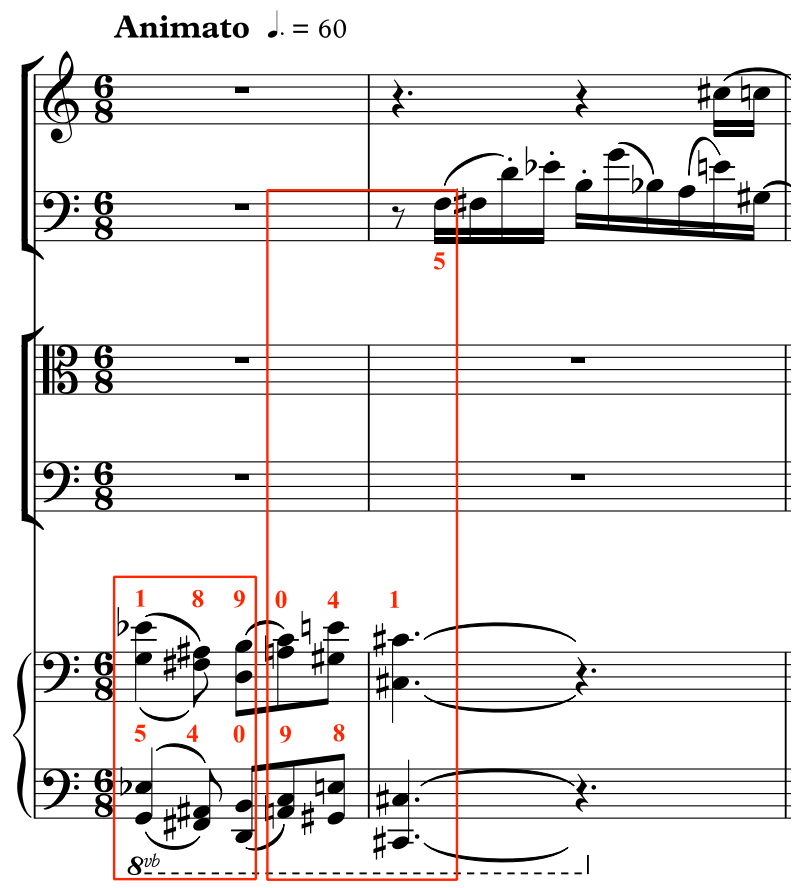

Fonte - Elaboração das autoras. 
Outras coleções inversionalmente simétricas foram usadas por Eunice em seu Quinteto, como a octatônica, no c. 67 , observada na parte do piano ${ }^{8}$. O conjunto correspondente aos sons empregados pela compositora é o 8-28 (l0 134679 10), e os sons apresentados são Si, Ré\# Fá, Fá\#, Lá, Do, Sol\#, Ré.

Figura 3: Coleção octatônica presente no conjunto 8-28, em Quinteto Schoenberg, mapeado na parte do piano (c. 67).

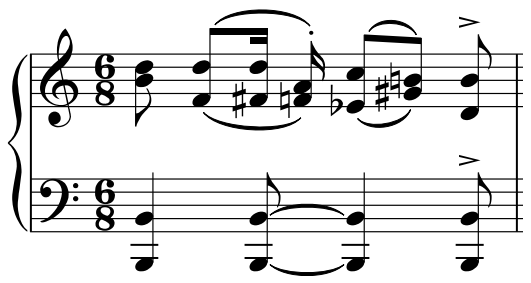

Fonte - Elaboração das autoras.

\section{O Quinteto Schoenberg: impressões e análise}

O Quinteto Schoenberg (ou Ommagio a Schoenberg) foi escrito em agosto de 1949 em São Paulo, após Eunice retornar de sua prolongada estadia na Europa. O manuscrito original possui 20 páginas e a peça para clarinete, clarinete baixo (ou clarone), viola, violoncelo e piano possui cerca de 6 minutos de duração. Sua estreia ocorreu no XXIV Festival da Sociedade Internacional de Música Contemporânea, realizado no ano de 1950 em Bruxelas. Esta foi a única peça latino-americana apresentada no evento.

Entre suas mais belas composições, figuram o "Negrinho do pastoreio", "Canto do soldado morto", e o Quinteto para viola, cello, duas clarinetas e piano, este último premiado num concurso que se realizou recentemente entre compositores das Américas, e também a única obra sul-americana que os organizadores do concurso acharam digna de figurar no festival da Sociedade de Música Contemporânea, cuja realização, em Bruxelas se deu em julho deste ano. ([s.n.], 1950, apud KATUNDA, c.1925-c.1970).

Sua composição "Três Líricas Gregas”, para vozes e orquestra de câmara e seu "Quinteto" sobre motivos nordestinos foram a única obra de artista americano a ser apresentada no Festival da Sociedade Internacional de Musica

\footnotetext{
${ }^{8} \mathrm{O}$ termo 'coleções referenciais' é definido por Vasconcelos $(2014$, p. 13) como conjuntos de classes de alturas não ordenados, que atuam como elementos unificadores por suas propriedades abstratas específicas. Como exemplos podem ser apontadas a coleção diatônica, a de tons inteiros, a octatônica, entre outras.
} 
Contemporânea realizado na Bélgica. (SILVEIRA, 1952, apud KATUNDA, c.1925-c.1970).

Diferentemente das peças compostas por Eunice exclusivamente a partir do dodecafonismo, como Quatro epígrafes e Cantos à morte, ou até mesmo obras realizadas antes de seu contato com a moderna técnica de composição, como Negrinho do Pastoreio, observa-se que a peça Quinteto Schoenberg foi realizada pela compositora a partir da combinação de elementos da música brasileira com a técnica dodecafônica. De acordo com afirmações de Koellreutter e Ana Stela Schic, o quinteto de Eunice reúne elementos da música brasileira, em especial "temas nordestinos", e uma linguagem dodecafônica, ou seja, atonal.

\begin{abstract}
Ao mesmo tempo que a Assembleia, haverá em Bruxelas o $24^{\circ}$ Festival de Música Contemporânea, no qual Eunice Catunda, cujo quinteto intitulado "Homenagem a Schoenberg" foi escolhido pelo Júri Internacional, sendo essa a única composição de autoria de músico latino-americano, que figura em seu programa. O quinteto é para clarinete, clarone, viola, celo e piano e, embora seja de fatura dodecafônica, apresenta características da música brasileira que se assim emprestam feição de todo particular à linguagem atonalista dessa compositora moderna. (KOELLREUTTER, 1949, apud KATUNDA, c.1925c.1970).
\end{abstract}

Eunice Catunda já se apresentou em público em várias cidades do Brasil e do exterior (Argentina, Uruguai, Italia, Suiça), executando obras antigas e modernas; compôs inúmeras obras, entre as quais: "O Negrinho do pastoreio", "Quatro poemas à morte", - para orquestra, que foram gravados e irradiados pela Rádio Zurique em primeira audição sob a direção de Hermann Scherchen, "Canto do Soldado Morto" - cantata para vozes e orquestra sobre texto de Rossine Camargo Guarnieri, e ainda "Três Figuras Gregas" - para vozes e orquestra de câmera e "Quinteto" sobre motivos nordestinos, sendo estas duas últimas obras apresentadas no Festival da Sociedade Internacional de Música Contemporanea de 1950 realizado na Bélgica, constando Eunice Catunda como a única autora americana apresentada. (SCHIC, 1951, apud KATUNDA, c.1925-c.1970).

O Quinteto inicia-se com uma breve introdução em acordes apresentada nos compassos 1 e 2. Neste pequeno trecho, que utiliza o registro grave do instrumento, Eunice Katunda apresenta alguns dos materiais básicos que desenvolverá por toda a peça: serie dodecafônica, figuras de colcheias, intervalos de $2 \mathrm{~m}, 3 \mathrm{~m}$ e $3 \mathrm{M}$ e melodia em contraponto paralelo. 
Figura 4: Introdução em acordes apresentada pelo piano nos c. 1-2, com indicação de serie dodecafônica.

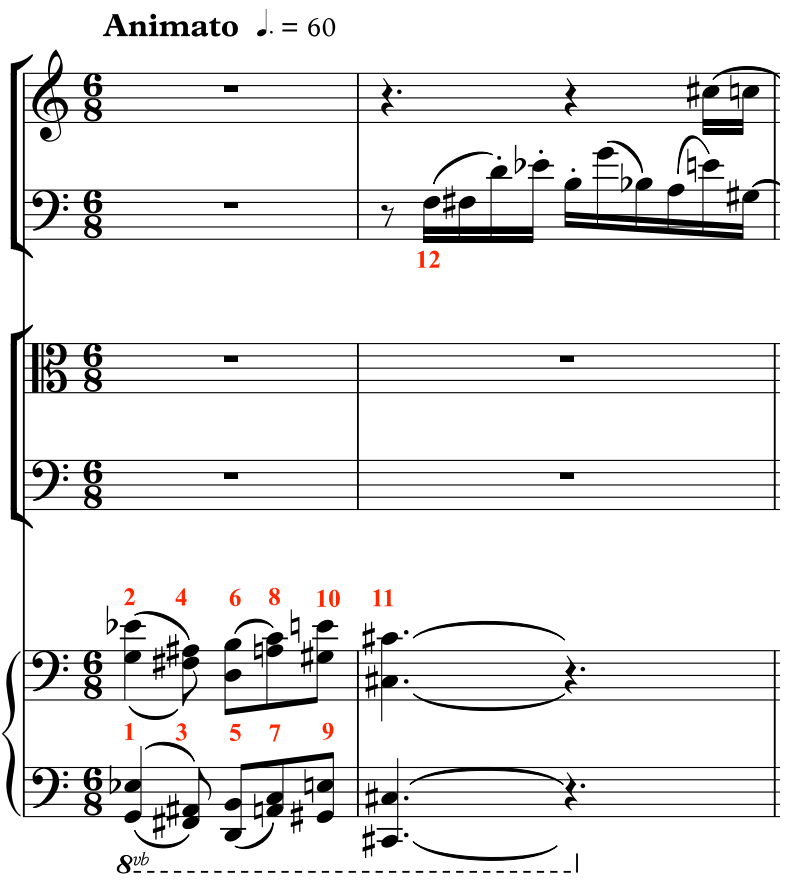

Fonte - Elaboração das autoras.

Apesar de ser apresentada pelo piano, a primeira série formada pelos sons \{Sol, Mib, Fá\#, Lá\#, Ré, Si, Lá, Do, Sol\#, Mi, Do\#, Fá\} se completa com uma nota feita pelo clarinete baixo, como mostrou a figura 4. Como foi dito anteriormente, é possível observar na serie completa a presença de dois hexacordes iguais e inversionalmente simétricos. Os elementos de cada um destes hexacordes formam o conjunto 6-20 [0 $\begin{array}{lll}0 & 1 & 4\end{array}$ 8 9], também denominado conjunto hexatônico.

Nos exemplos que se seguem, os sons estão indicados por suas cifras correspondentes. A série foi chamada $\mathrm{O}_{7}$ por ser a primeira serie original apresentada, e por se iniciar no sétimo elemento da coleção cromática, o som Sol (G).

Quadro 1 - Serie dodecafônica $\mathrm{O}_{7}$ empregada inicialmente por Eunice Katunda.

\section{$\mathrm{O}_{7}\{\mathrm{G} \mathrm{Eb}$ F\# A\# D B A C G\# E C\# F $\}$}

Fonte - Elaboração das autoras. 
Quadro 2 - Hexacordes 1 e 2 empregados por Eunice Katunda na serie $\mathrm{O}_{7}$.

\section{$\mathrm{H} 1\{\mathrm{G} \mathrm{Eb}$ F\# A\# D B $\}$ e H2 $\{$ A C G\# E C\# F $\}$}

Fonte - Elaboração das autoras.

A maneira como os sons estão dispostos na serie $\mathrm{O}_{7}$ também faz com que os hexacordes sejam inversos entre si em relação a seus intervalos. Estes estão marcados em quantidade de semitons:

Quadro 3 - Intervalos inversionalmente simétricos presentes na serie $\mathrm{O}_{7}$.

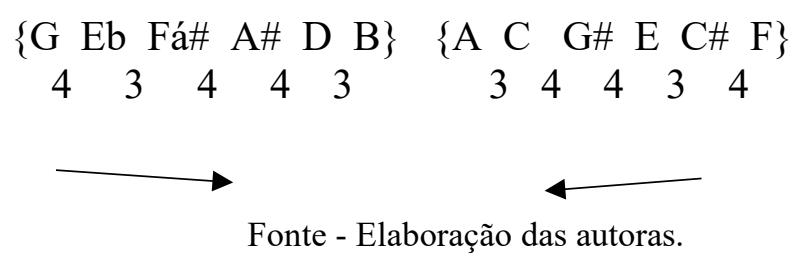

Os dois hexacordes são separados por uma $2 \mathrm{M}$ (4), que funciona como eixo de simetria. No exemplo que se segue os elementos são indicados por seus números correspondentes na coleção cromática, de 0 a 11, para facilitar a relação com os conjuntos de Allen Forte:

Quadro 4 - Intervalos inversionalmente simétricos presentes na serie $\mathrm{O}_{7}$.

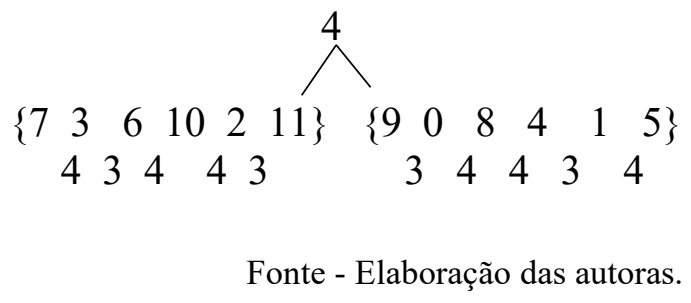

Serie similar, porém posicionando os hexacordes em ordem inversa, foi usada por Luigi Nono em sua obra Variazioni Canoniche sulla serie dell'op. 41 di Arnold Schoenberg ${ }^{9}$. Diferentemente de Eunice Katunda, o compositor ordenou os elementos de

\footnotetext{
${ }^{9}$ Cf.: RIZZARDI, apud, OLSCHKI, 2004, p. 12.
} 
cada hexacorde de forma a que resultassem também inversionalmente simétricos, separados por uma $2 \mathrm{M}(4)$.

Quadro 5 - Intervalos inversionalmente simétricos presentes na serie de Luigi Nono.

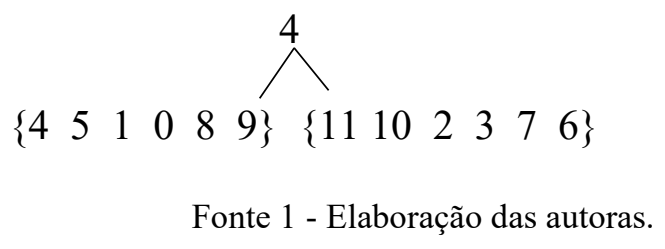

Em termos de intervalos, predominam a 3m, a $3 \mathrm{M}$ e suas inversões, como pode ser visto nas díades apresentadas no Tema Introdutório do Quinteto Schoenberg: Sol-Mib; Fá\#-Lá\#; Ré-Si; Lá-Dó e Sol\#-Mi. A 2m também aparece entre notas das linhas horizontais, como Sol-Fá\#, Si-Dó e Lá-Sol\#.

Figura 5: Intervalos de 3m, 3M e $2 \mathrm{~m}$ no compasso 1.

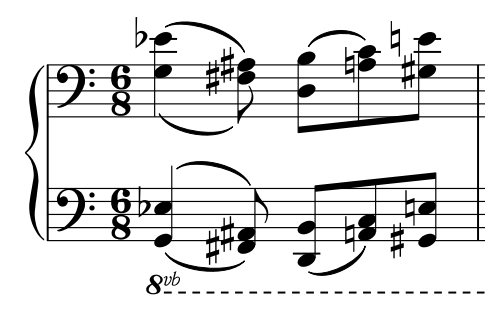

Fonte - Elaboração das autoras.

Esta serie $\left(\mathrm{Ol}_{7}\right)$ reaparece nos compassos 4 e 5 na parte do piano, variada em semicolcheias. 
Figura 6: Serie $\mathrm{O} 1{ }_{7} \mathrm{em}$ semicolcheias (c. 4-5).

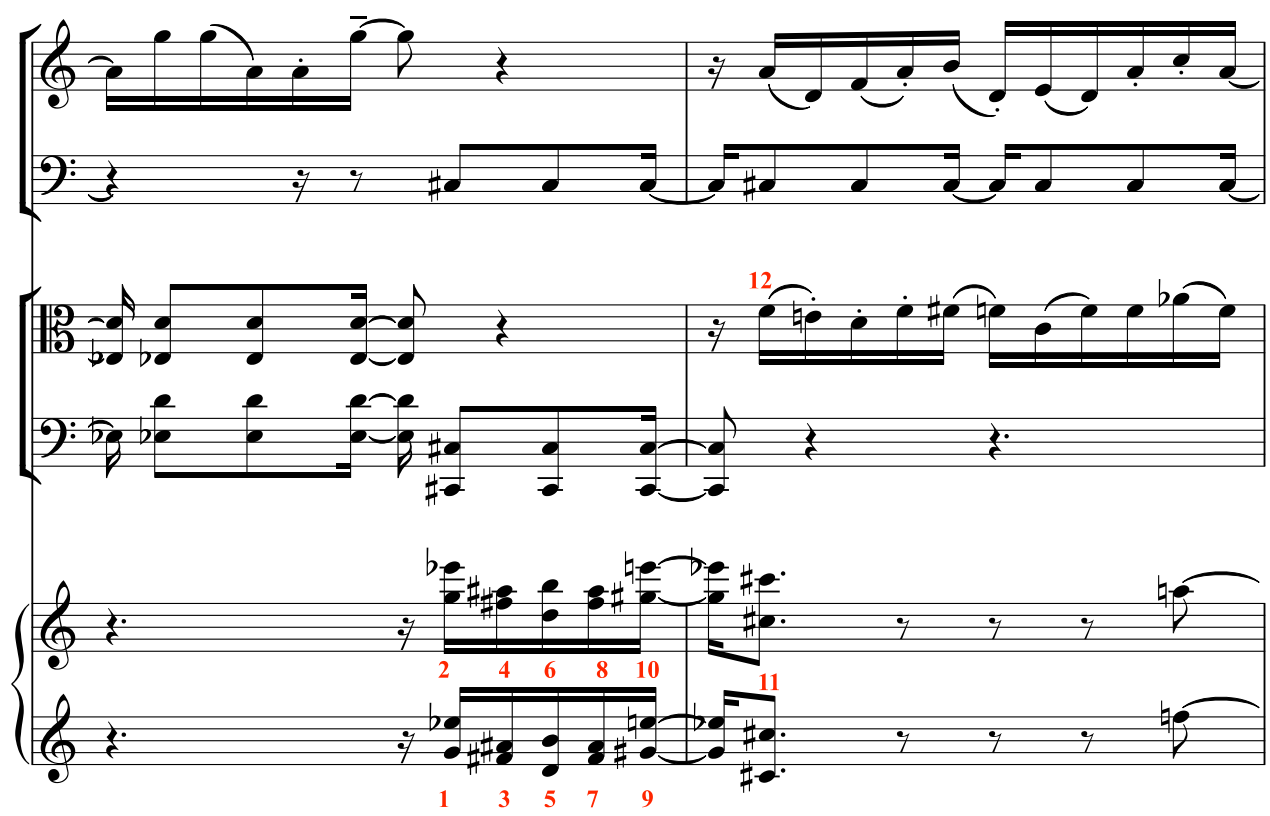

Fonte - Elaboração das autoras.

Uma nova série chamada aqui de O2, é apresentada no segundo compasso pelos clarinetes. De maneira igual à primeira serie da peça $\left(\mathrm{O}_{7}\right)$, a serie referente ao c. $2\left(\mathrm{O} 2_{5}\right)$ é formada por dois hexacordes de mesmo conjunto, o 6-15 (l $\begin{array}{lllll}0 & 1 & 2 & 4 & 5\end{array}$ ).

Figura 7: Serie dodecafônica O2 5 empregada por Eunice Katunda (c. 2).

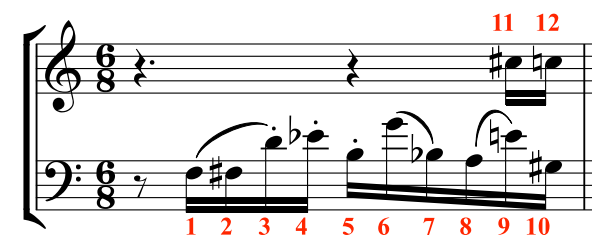

Fonte - Elaboração das autoras.

Quadro 6 - Hexacordes 6-15 empregados por Eunice Katunda em O25.

$\mathrm{H} 1\{\mathrm{~F} \mathrm{~F} \# \mathrm{DEb} \mathrm{B} \mathrm{G}\}$ e $\mathrm{H} 2\{\mathrm{Bb}$ A E G\# C\# C $\}$

Fonte - Elaboração das autoras.

No compasso 6, Eunice Katunda usará o sistema de rotação de alguns elementos da serie $\mathrm{O}_{7}$ na linha feita pelo cello. Ela omite também o $11^{\circ}$ elemento da serie, que seria o 
Do\#, e faz uso de enarmonia nos sons Lá\#, usando Sib, e Sol\#, usando Láb. Na figura que se segue estas notas são escritas em vermelho. Chamamos a esta serie O1', e, como se inicia no $3^{\circ}$ grau, $\mathrm{O}^{\prime}{ }_{3}$.

Quadro 7: Serie $\mathrm{O1}$ ' ${ }_{3}$, indicando a rotação dos elementos Eb-G e C-A, além da omissão do C\# (c. 6).

\section{$\mathrm{O} 1_{3}^{\prime}\{\mathrm{Eb} \mathrm{G}$ F\# A\# D B C A G\# E F $\}$}

Fonte - Elaboração das autoras.

Figura 8: Mapeamento da Serie $\mathrm{O} 1_{3}{ }_{3}$ com rotação e omissão de elementos apresentada pelo cello (c. 6).

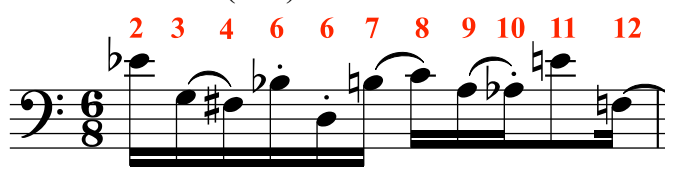

Fonte - Elaboração das autoras.

É importante notar que, apesar de variada pela rotação dos dois elementos iniciais de cada hexacorde, esta $\mathrm{Ol}_{1}{ }_{3}$ mantém os conjuntos 6-20 (l $\left.\begin{array}{lllll}0 & 1 & 4 & 5 & 8\end{array}\right)$ em cada um deles, porém, com a omissão de um elemento (o Do\#) no segundo hexacorde.

Assim como na figura anterior, foram mapeados outros trechos em que a série dodecafônica $\mathrm{Ol}_{3}{ }_{3}$ aparece de maneira melódica e completa, como na parte do violoncelo e viola no c. 17 (com rotação entre o $10^{\circ}$ som, Mi, e o $11^{\circ}$, Do\#) e no clarinete nos c. 5051 (com rotação entre o $11^{\circ}$ som, Do\#, e o $12^{\circ}$, Fá).

Quadro 8 - Serie $\mathrm{O}^{\prime}{ }_{3}$ com rotação do $10^{\circ}$ e $11^{\circ}$ elementos (c. 17).

\section{O1'3 $\{\mathrm{Eb}$ G F\# A\# D B C A G\# C\# E F $\}$}

Fonte - Elaboração das autoras. 
Figura 9: Mapeamento da Serie $\mathrm{O}_{1}^{\prime}{ }_{3}$ com rotação do $10^{\circ}$ e $11^{\circ}$ elementos (c. 17) na parte do violoncelo e viola.

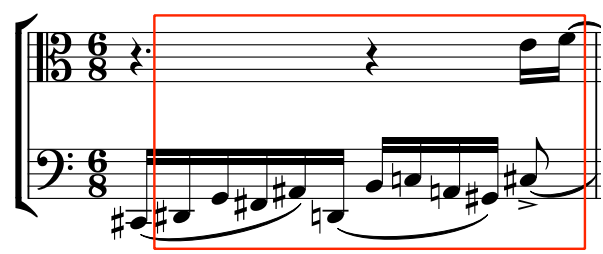

Fonte - Elaboração das autoras.

Quadro 9 - Serie $01^{\prime}{ }_{3}$ com rotação do $11^{\circ}$ e $12^{\circ}$ elementos (c. 50-51).

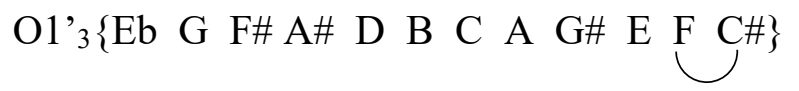

Fonte - Elaboração das autoras.

Figura 10: Mapeamento da Serie $\mathrm{O}_{1}{ }_{3}$ com rotação do $11^{\circ}$ e $12^{\circ}$ elementos na parte do clarinete (c. 50$51)$.

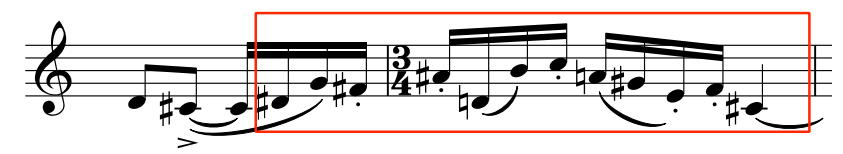

Fonte - Elaboração das autoras.

No entanto, também é importante observar que, em alguns casos, a rotação entre os elementos da serie se dá trazendo o $11^{\circ}$ elemento (Do\#) para o início da mesma. Neste caso, o hexacorde inicial passa a ser o conjunto 6-Z44 ( ( $\begin{array}{lllll}0 & 1 & 2 & 5 & 6\end{array}$ ), apresentado duas vezes seguidas de maneira melódica nos c. 95-96 pelo clarinete e clarinete baixo, enquanto o cello apresenta o segundo hexacorde desta nova serie no c. 96. A nova serie foi aqui denominada $\mathrm{O} 1{ }^{\prime}$, já que se inicia no grau 1. Já o segundo hexacorde corresponde ao conjunto 6-Z19 (0 13347 8), que, por sua vez. É complementar ao 6-Z44 e tem o mesmo vetor intervalar daquele.

Quadro 10 - Serie O1' ${ }_{1}$, formada pela rotação do $11^{\circ}$ elemento (C\#) para a posição inicial. (c. 95-96).

$$
\text { O1' } 1\{\text { C\# D\# G F\# A\# D B C A G\# E F }\}
$$

Fonte - Elaboração das autoras. 
Figura 11: Mapeamento da Serie O1' ${ }_{1}$, com repetição do hexacorde inicial pelos clarinetes e apresentação do segundo hexacorde pelo cello (c. 95-96).

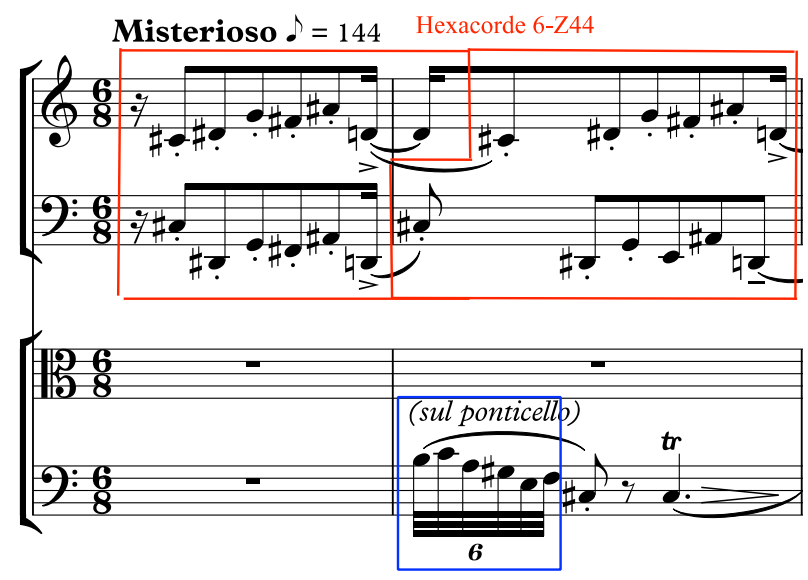

Fonte - Elaboração das autoras.

Quadro 11 - Hexacordes H1 e H2 empregados por Eunice Katunda em O’ ${ }_{1}$.

H1 $\{$ C\# D\# G F\# A\# D $\}$ e H2 $\{$ B C A G\# E F $\}$

Fonte - Elaboração das autoras.

A serie $01{ }_{1}$ aparecerá de forma linear e completa nas linhas dos clarinetes nos c. 97-98, enquanto a viola e o cello apresentam os dois hexacordes em ordem invertida de aparição. A compositora repete o som Do\# $(\mathrm{C \#})$ entre os hexacordes que se encontram em ordem invertida.

Figura 12: Mapeamento da Serie $\mathrm{O}^{\prime}{ }^{1}$, completa feita pelos clarinetes (em vermelho) e em ordem invertida de hexacordes feita pela viola e cello (c. 97-98). Nota-se a repetição do som C\# nestas linhas.

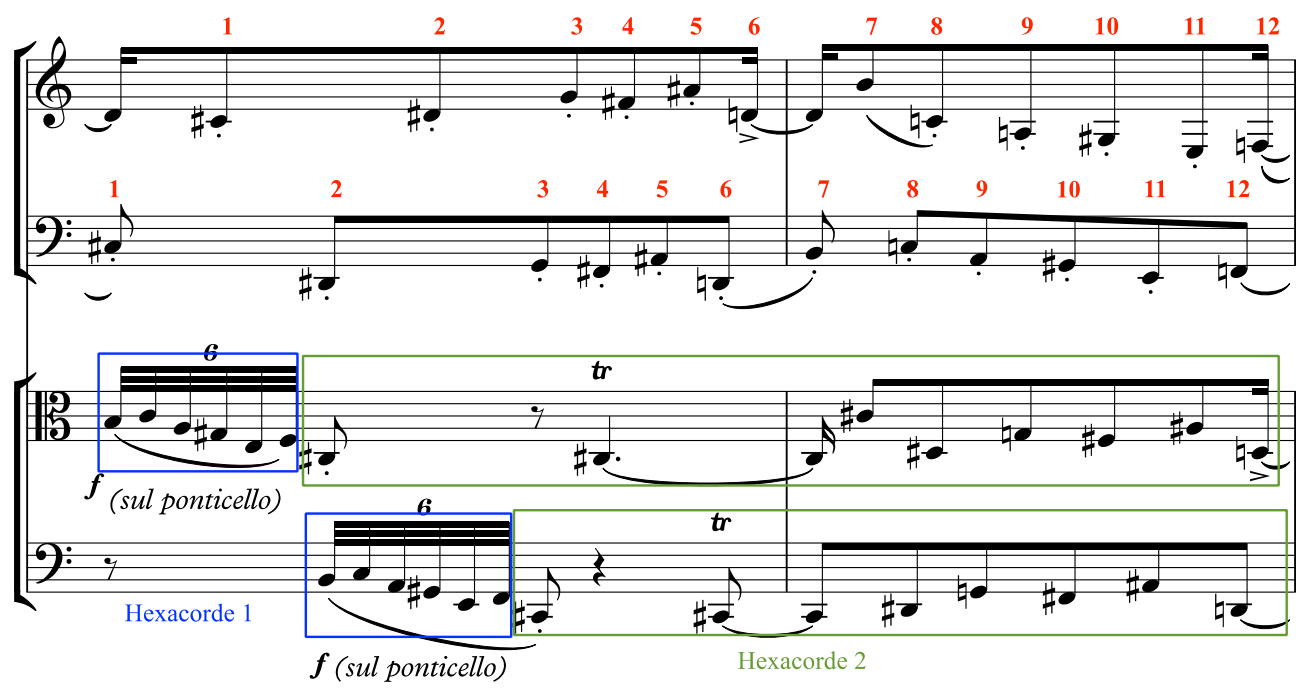

Fonte - Elaboração das autoras. 
É interessante notar o pensamento de variação progressiva no tratamento dado por Eunice Katunda à serie inicial de seu Quinteto, enquanto que a segunda serie apresentada, O2, é praticamente abandonada. No entanto, nota-se uma nucleação desta serie em subconjuntos de três e quatro notas ao longo da peça.

Como exemplo, tem-se a melodia sul ponticello realizado pelo cello nos c. 10-13, no qual verifica-se a presença do tricorde 3-3 (llll), que é formado pelos três primeiros sons da série $\mathrm{O} 2$.

Figura 13 - Subconjunto 3-3 (o 14 ) mapeado na melodia realizada pelo cello (c. 10-13).

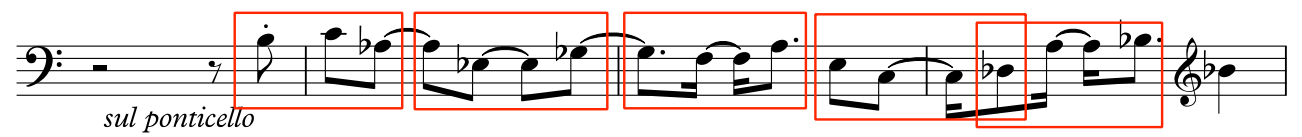

Fonte - Elaboração das autoras.

Outro exemplo desta nucleação pode ser observado entre os c. 26-27. Neste trecho, no qual há uma finalização de seção, o tetracorde 4-19 (l $\left.\begin{array}{lll}0 & 1 & 4\end{array}\right)$, formado pelas últimas quatro notas da serie $\mathrm{O} 2$, pode ser mapeado em todos os instrumentos do quinteto.

Figura 14: Subconjunto 4-19 (0 14 8) mapeado em Quinteto Schoenberg (c. 27-28).

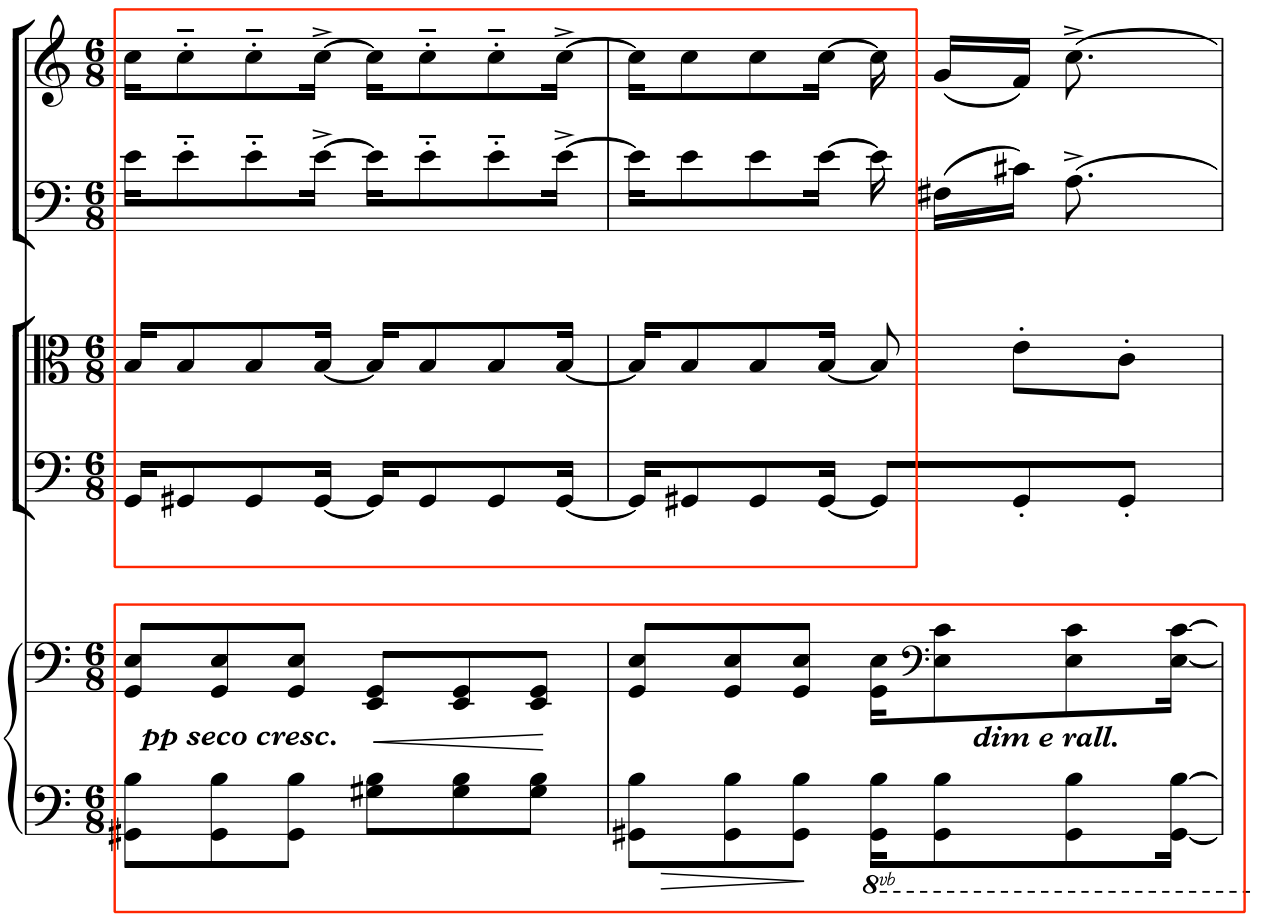

Fonte - Elaboração das autoras. 


\section{O Quinteto Schoenberg: para além do dodecafonismo}

Como foi dito na introdução deste artigo, Eunice Katunda se inspira na Ode to Napoleon Buonaparte de Arnold Schoenberg por aspectos que vão além do uso da técnica dodecafônica. Assim como Luigi Nono em suas variações sobre um tema do compositor da Segunda Escola de Viena, ela admira o caráter humanista inserido por Schoenberg em sua obra Op. 41.

Neste sentido, a compositora insere temas de inspiração nacional, nordestina, em seu Quinteto. Estes temas são preparados por semicolcheias ininterruptas, também inspiradas na citada composição de Schoenberg.

O Quinteto pode ser dividido em 10 partes, indicadas por mudanças de andamento e caráter.

Quadro 12 - Seções e andamentos especificados na partitura de Quinteto Schoe
\begin{tabular}{|c|c|}
\hline NÚMERO DOS COMPASSOS & ANDAMENTO ESPECIFICADO \\
\hline $1-7$ & Animato $(\mathrm{X}=60 \mathrm{ca})$ \\
\hline $8-16$ & $(\mathrm{X}=72 \mathrm{ca})$ \\
\hline $16-28$ & Menos X $=42$ \\
\hline $29-33$ & Piu calmo e libero \\
\hline $34-42$ & Piu lento X $=56$ \\
\hline $43-52$ & Calmo X $=66$ ca \\
\hline $53-72$ & Meno mosso X $=50$ \\
\hline $73-94$ & Meno mosso X $=\mathrm{X}=72$ \\
\hline $95-107$ & Misterioso $(\mathrm{X}=144 \mathrm{ca})$ \\
\hline $108-136$ & Piu calmo, cantando \\
\hline
\end{tabular}

Fonte - Elaboração das autoras.

Após a Introdução, que se estende do c. 1 ao 6, inicia-se no c. 7 uma espécie de ponte para a Seção A, em métrica 3/4. Eunice Katunda varia a métrica simétrica inicial 6/8 pela inserção de uma colcheia, passando para a assimétrica 7/8. Com este procedimento a compositora prepara o primeiro tema de caráter nordestino que entrará no c. $11^{10}$ (e seu anacruse) e que é realizado por meio do efeito de sul ponticello.

\footnotetext{
${ }^{10}$ A alternância, justaposição ou mesmo a sobreposição das métricas 6/8 e 3/4 são características da música latino-americana.
} 
Figura 15: Passagem da métrica 6/8 para 3/4 pela inserção de um compasso em 7/8 (c. 7-8)

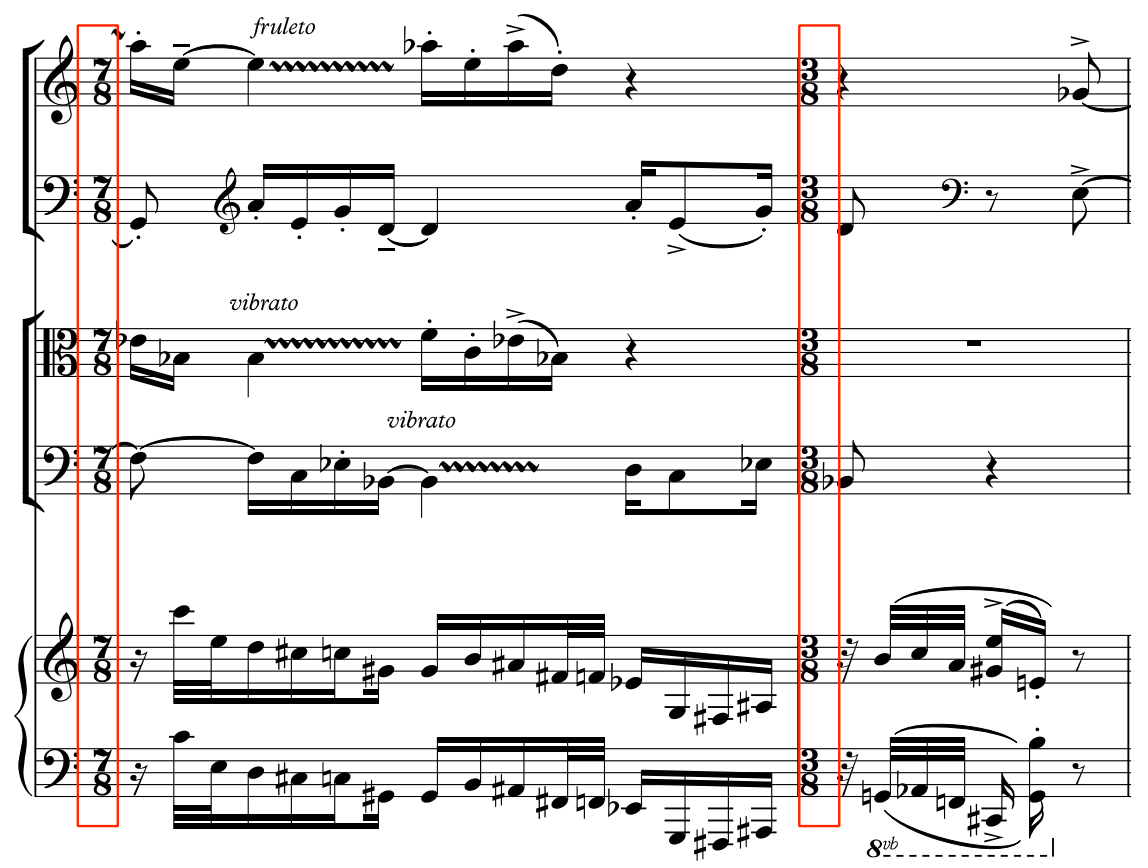

Fonte - Elaboração das autoras.

O primeiro tema rítmico nordestino apresentado (aqui chamado de Tema nordestino 1) é precedido de dois compassos em semicolcheias sincopadas tocadas pelo clarinete e clarinete baixo. Este trecho apresenta uma colcheia em anacruse no c. 8, cujo prolongamento anuncia o efeito sincopado que marcará o Tema - um dos rítmos de caráter popular nordestino citadas por Ana Stela Schic (1951) e por Koellreutter (1949), conforme já mencionado. As semicolcheias enfatizam o intervalo de $2 \mathrm{~m}$.

Figura 16: Semicolcheias sincopadas precedidas de anacruse (c. 8-10)

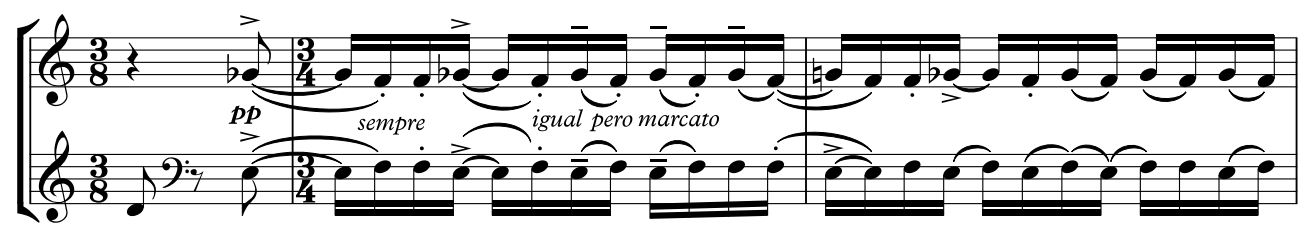

Fonte - Elaboração das autoras.

O tema será introduzido pela viola e violoncelo no c. 11. Apresentado a 3 vozes em homofonia, como a introdução em acordes, esta passagem reúne o já mencionado tricorde 3-3 (formado pelos três primeiros sons da série O2) e elementos característicos do folclore nacional - como ritmos pontuados, síncopas, etc. 
As semicolcheias sincopadas dos compassos 9 e 10 seguem formando um acompanhamento para a melodia contrapontística do Tema Nordestino 1, numa textura em camadas que combina melodia acompanhada e contraponto com perfil melódico de 2as menores.

Figura 17: Tema Nordestino 1, sincopado (compassos 11 - com anacruse - a 13).

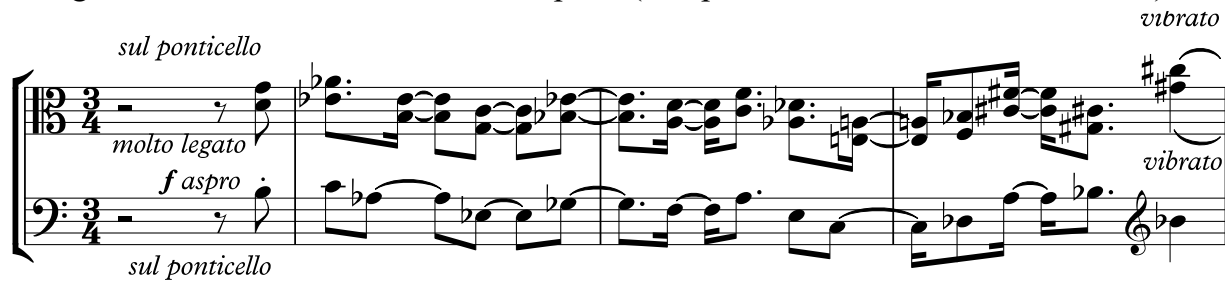

Fonte - Elaboração das autoras.

Este trecho em semicolcheias com intervalo de $2 \mathrm{~m}$ servindo de acompanhamento para uma melodia em acordes também se remete à Ode to Napoleon de Schoenberg, como mostra a figura a seguir:

Figura 18: Semicolcheias em intervalos de semitom em Ode to Napoleon (c. 1)

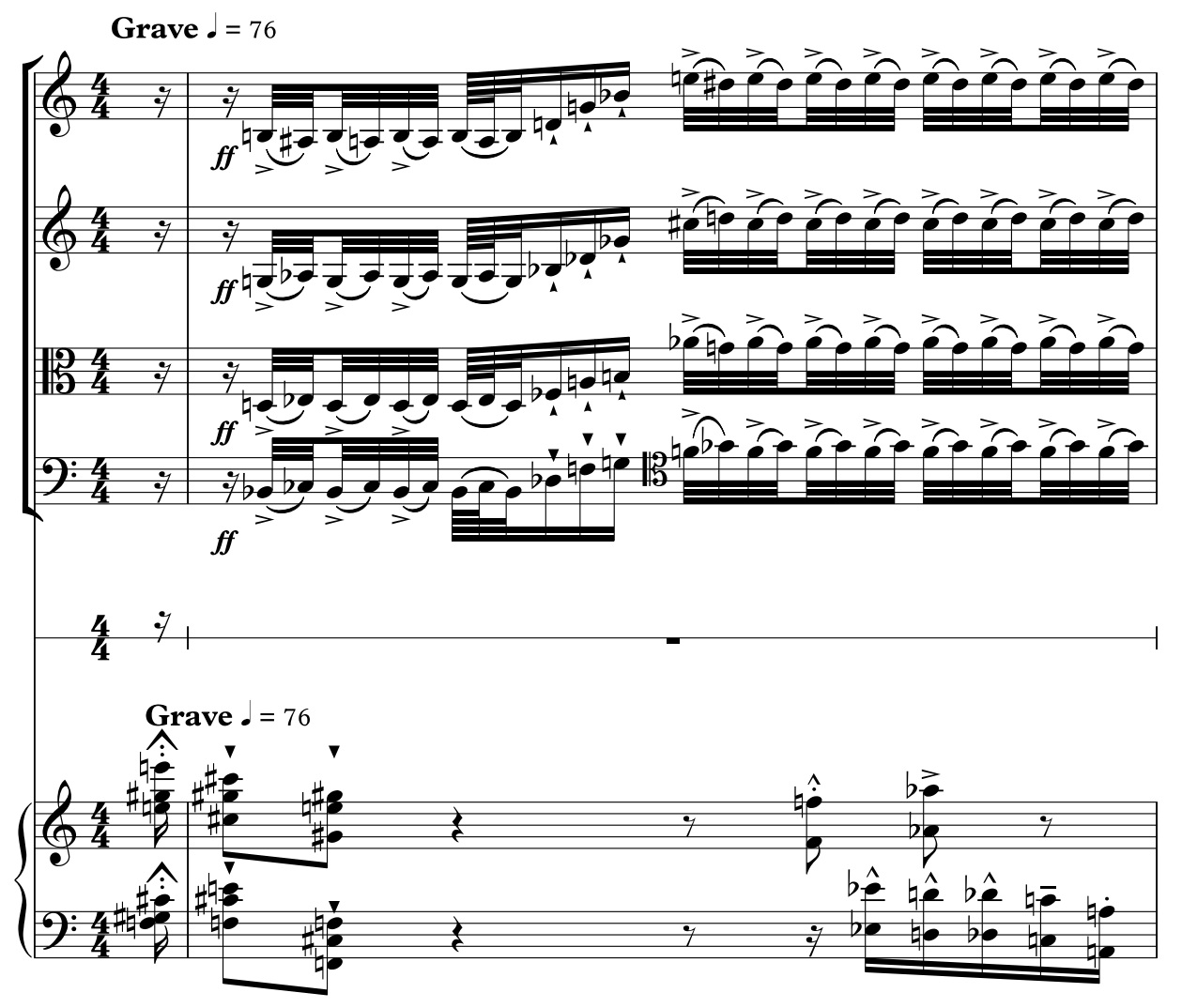

Fonte - Elaboração das autoras. 
Verifica-se também a presença de um segundo tema, aqui denominado Tema Nordestino 2, com características de melodia popular brasileira. Apresentado pelos clarinetes em cânone ${ }^{11}$, o tema em Do mixolídio surge pela primeira vez no c. 34 , e se estende até o c. 41.

Figura 19: Tema Nordestino 2 apresentado pelo clarinete (c. 34-41).

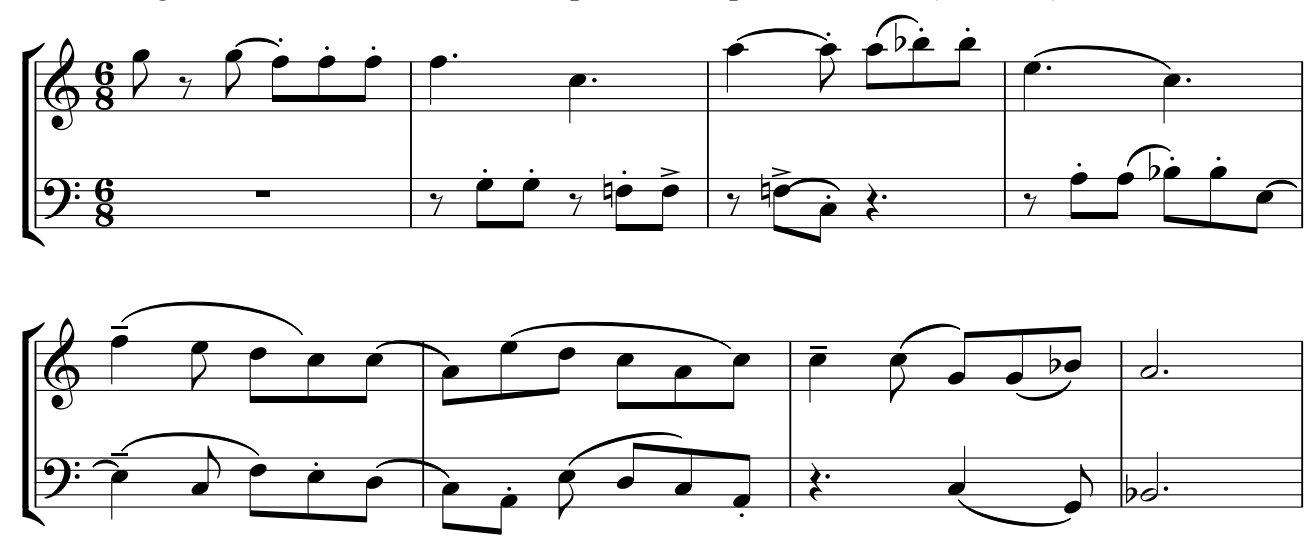

Fonte - Elaboração das autoras.

Este tema principal aparece mais duas vezes ao longo da peça, sendo realizado de maneira variada e em outros modos pela viola nos c. 53-60 e pelo piano nos c. 101-105.

Figura 20: Tema Nordestino 2 apresentado na viola em Lá mixolídio (c. 53-60).

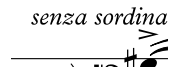

Fonte - Elaboração das autoras.

\footnotetext{
${ }^{11}$ No início da partitura está indicado "clarinete em sons reais". Sendo assim, não se faz necessário considerar transposições para estes instrumentos ao longo da peça.
} 
Figura 21: Tema Nordestino 2 da peça apresentado pelo piano em Mi Mixolídio (c. 101-105).
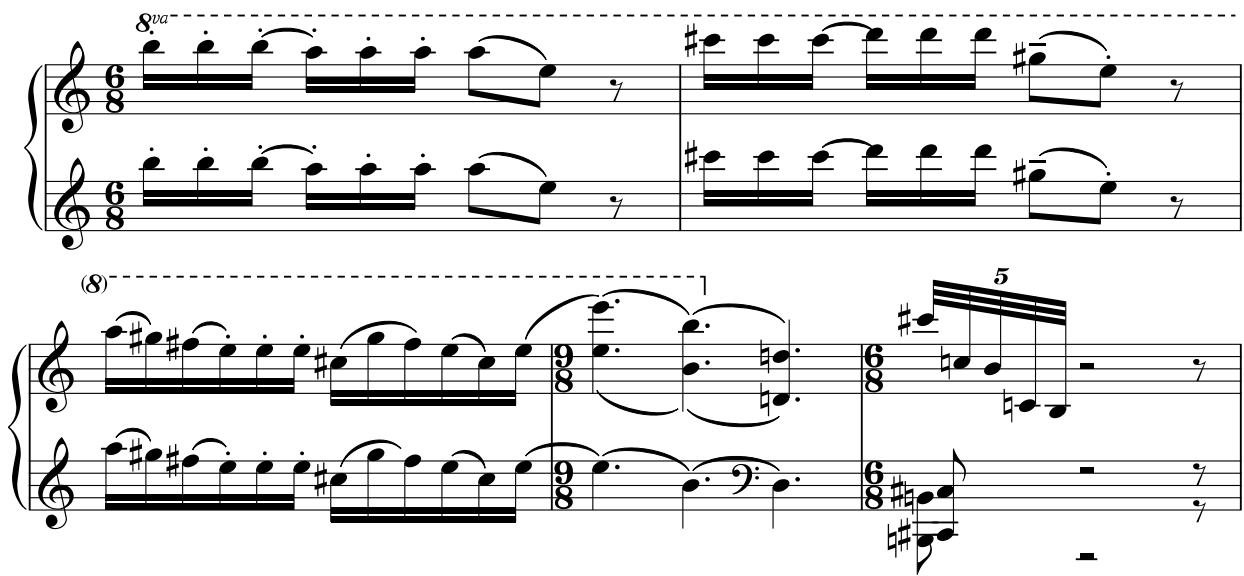

Fonte - Elaboração das autoras.

Eunice Katunda era conhecedora de diversos temas folclóricos, tanto por ter estudado com professores e professoras vinculados(as) a esta estética em sua Fase de Formação (até 1945) como por ter feito pesquisas de campo, especialmente após o rompimento com o Música Viva. Além disso, ela conheceu profundamente o ensaio de Mario de Andrade intitulado Ensaio sobre a Música Brasileira - que reúne exemplos de cantos populares de diversas regiões do Brasil - publicado inicialmente em 1928 pelo musicólogo. Como atesta Melina de Lima Peixoto (2009, p. 8), "Katunda, em depoimento pessoal a Kater, declarou que tinha 'no Ensaio sobre a música brasileira seu predileto livro de cabeceira"”.

Não foi possível identificar entre os exemplos reunidos por Mario de Andrade os temas nordestinos empregados por Eunice em seu Quinteto, mas, alguns exemplos coletados pelo musicólogo podem ter lhe servido de inspiração, tanto pelos ritmos sincopados como pelas melodias com sons repetidos e terminações em intervalos de terças - ascendentes ou descendentes.

Figura 22: Exemplo do tema popular "Mulher Rendeira" coletado por Mario de Andrade (1972, p. 115)

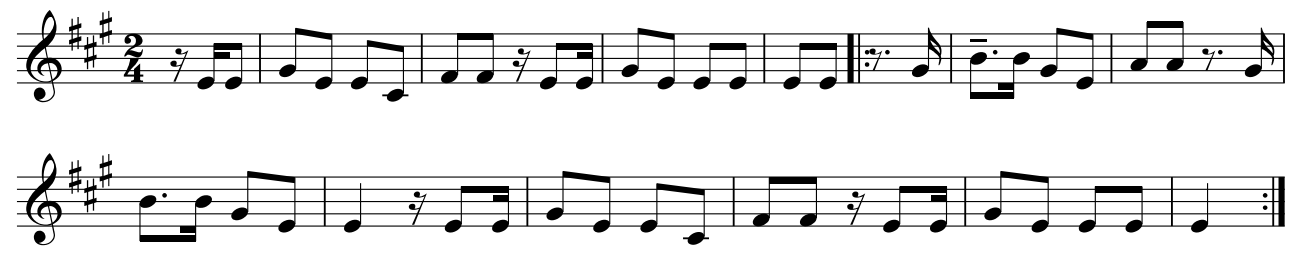

Fonte - Elaboração das autoras. 
Figura 23: Exemplo do tema popular "Nunca mais eu vi”" coletado por Mario de Andrade (1972, p. 111).

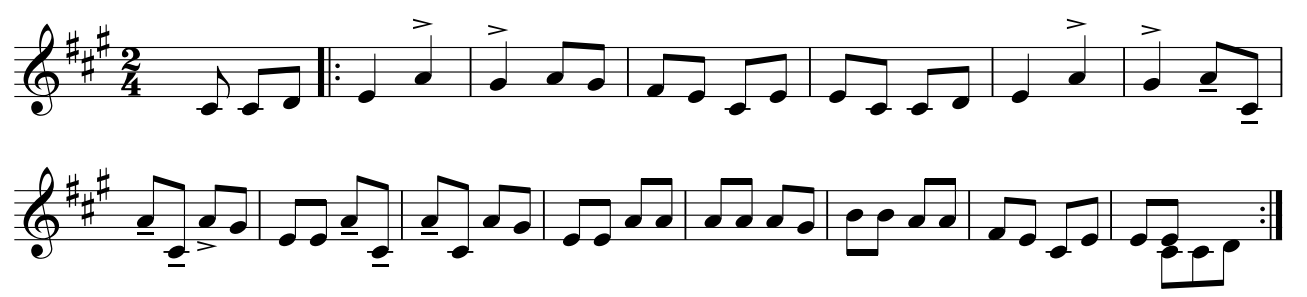

Fonte - Elaboração das autoras.

Por fim, o acorde que encerra o Quinteto Schoenberg é baseado na sobreposição das 4J D\#, G\# e C\#, feito pelos clarinetes, viola e violoncelo. O piano realiza um trilo sobre o cluster C, C\#, D, D\#, E ( $\begin{array}{llll}0 & 1 & 2 & 3\end{array}$ 4), que causa efeito retumbante ao se iniciar em dinâmica $p p p$ no c. 135 , crescer em intensidade e novamente diminuir no c. 136 até se dissipar.

Figura 24: Acorde final em 4j sobre trilo feito pelo piano (c. 136)

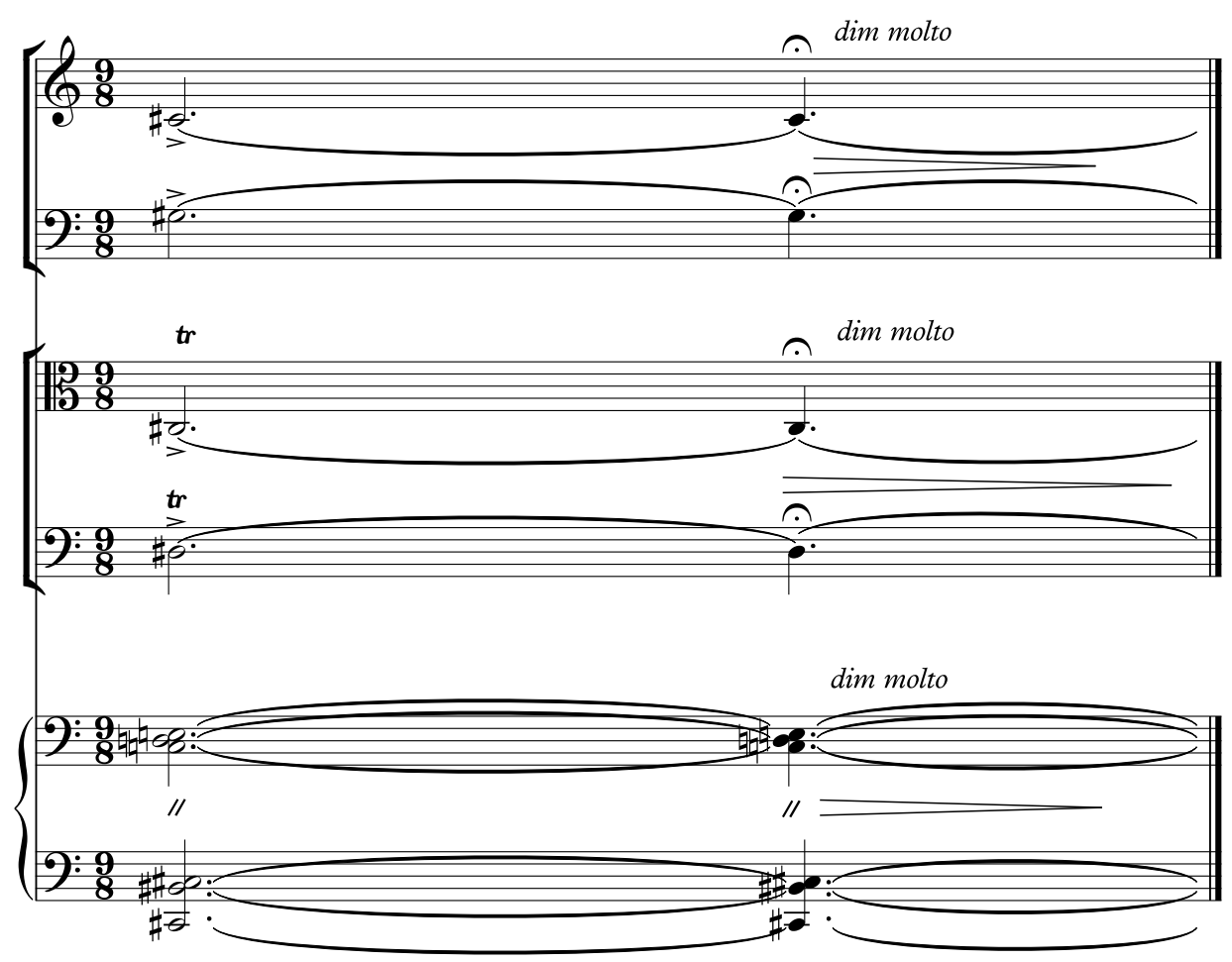

Fonte - Elaboração das autoras.

Este final completa a homenagem de Eunice Katunda ao compositor Arnold Schoenberg, cuja Ode to Napoleon Buonaparte também se encerra com um acorde retumbante de Eb M, aludindo à Sinfonia Eroica de Ludwig van Beethoven. 
Figura 25: Acorde final de EbM em Ode to Napoleon (c. 267) de Arnold Schoenberg

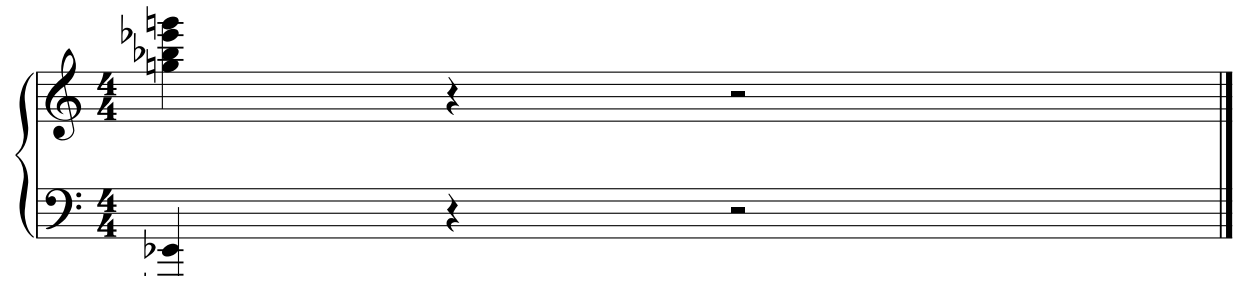

Fonte - Elaboração das autoras.

\section{O rompimento com Koellreutter e o abandono da técnica dodecafônica: textos e depoimentos de Eunnice Katunda}

Apesar de ter se interessado, compreendido e dominado a técnica dodecafônica como demonstra a complexidade estrutural e a maturidade composicional da autora em seu Quinteto Schoenberg -, Eunice Katunda se afastou desta linguagem quando rompeu com Hans-Joachim Koellreutter e com o grupo Música Viva. Esse rompimento ocorreu publicamente em 1950, após Eunice declarar, em carta endereçada a Camargo Guarnieri, seu apoio e agradecimento pela publicação da Carta aberta aos músicos e críticos do Brasil pelo compositor.

A Carta de Guarnieri, publicada em 17 de dezembro de 1950 no jornal O Estado de São Paulo, alertava a comunidade musical para o que ele considerava um perigo para a juventude que estudava composição, ou seja, a adoção de procedimentos formalistas (como o dodecafonismo) em detrimento do uso de materiais derivados do folclore nacional. A própria Eunice, bem como outros membros do grupo Música Viva especialmente Claudio Santoro -, já vinha questionando desde 1948 a pertinência ou não do uso da técnica dodecafônica por compositores(as) no Brasil.

Em um primeiro momento Eunice foi a favor da técnica, respondendo de modo contrário às ideias defendidas por Santoro em texto intitulado Música Contemporânea Brasileira em face das Resoluções e Apelo do Congresso de Compositores de Praga. Este texto, publicado por Santoro na revista Fundamentos em 1948 e divulgado após a participação do compositor no II Congresso de Compositores Progressistas de Praga, trazia argumentos contra o uso da técnica dodecafônica no nosso país.

Nós os compositores progressistas, que acreditamos na força nova que é o proletariado, não devemos desperdiçar energias quase inúteis, para fazermos indiretamente o jogo da classe dominante, ajudando a afirmar-se o conceito de "arte pela arte", participando do movimento abstracionista, colaborando enfim no ponto de vista de que o artista está desligado da sociedade, que ela reflete o seu interior, ficando desprovida de senso e realidade a participação que ele deve 
ter na luta do lado do povo e na defesa da real cultura. (SANTORO, apud KATER, 2001b, p. 268-269).

Como resposta a este documento, Eunice redige o texto Problemas musicais contemporâneos - publicada no jornal Folha de São Paulo em abril de 1950. O texto, escrito após seu retorno da Europa e consequente fixação na cidade de São Paulo, expõe argumentos a favor das ações promovidas pelo Música Viva como, por exemplo, as atividades de divulgação musical ampla e não somente de peças dodecafônicas, além da sua defesa ao uso da técnica schoenberguiana já que, segundo ela, "essa técnica veio servir a uma necessidade", configurando-se um "produto do processo dialético da evolução musical, uma emergência da arte musical" (Grifo da autora).

\begin{abstract}
Você conhece o esforço fantástico desprendido pelo nosso "Grupo Música Viva" no sentido de cumprir nosso dever de divulgação musical. Não só no sentido de divulgação de música dodecafônica. Esta se encontra mesmo em evidente minoria em nossos programas. Não só porque (apesar de nos acusarem de sistematicamente disso) não somos sectários, como também não existe quasi nada de música dodecafônica em gravações (nada de Dallapiccola). Um único concerto de Schoenberg, trechos da "Lulu", um concerto de Alban Berg e o não dodecafônico Pierrot Lunaire. Mais nada. Procuramos divulgar tudo o que podemos: Villa, Guarnieri, Santoro, Eunice Catunda, Guerra-Peixe, Prokofieff, Shostakovitch; sem preconceitos de tipo de música ou de categoria artística (KATUNDA, 1950, p. 8-9).
\end{abstract}

Dessa maneira, defende também a ideia de que "o grande público não aprova nem desaprova a dodecafonia", já que "não chega a ouvi-la". Segundo Eunice, "a música, não só a clássica como a moderna e a contemporânea é divulgada de maneira unilateral e viciosa", sendo esta "não cotada no mercado musical mundial."

Além disso, cita o sucesso que presenciou da obra dodecafônica $O$ fugitivo de Varsóvia, ${ }^{12}$ de Schoenberg, durante sua estadia na Europa. De acordo com ela, a peça de Schoenberg não chega a ser "formalista" já que sua música possui "conteúdo" e sua "forma serve a um determinado fim" $"$.

\begin{abstract}
Voltemos ainda as obras dodecafônicas. Ouvi, na Europa, a irradiação da primeira audição mundial de "O Fugitivo de Varsóvia" (realizado em 1948). Obteve estrondoso sucesso de público. Foi bisada. Creia-me Santoro: está longe de ser uma música sem conteúdo. Alí você vê que Schoenerbg reflete toda a sua solidariedade humana. Sente-se alí e muito intensamente, toda a tragédia da Polônia atormentada pela guerra. Não é música de ambientes rarefeitos, música de elocubrações estéticas. É música emocionante, profundamente viva!
\end{abstract}

\footnotetext{
${ }^{12}$ A peça Um Sobrevivente de Varsóvia, Op. 46 (1947), com duração de aproximadamente 6 e 7 minutos, consiste em um oratório para voz recitante, coro masculino e orquestra.

${ }^{13}$ Eunice também menciona em cartas sua empatia com outras peças de Schoenberg. De acordo com ela "o concerto para violino de Schoenberg foi uma das poucas obras na qual se revela a música como razão e motivo principal da obra". (KATUNDA, 1949, apud KATER, 2020, p. 149). Também declara que como pianista durante sua estadia na Europa, sua vontade era de "só tocar Bach e Schoenberg". (Idem, p. 143).
} 
Ouvi também o concerto de Schoenberg, para violino (1936). Logo depois, uma ópera de Hindemith e um ballet de Stravinski no último período: Orfeu. E comparando-se as obras de Schoenberg com as últimas produções de Stravinski e Hindemith, chega-se infalivelmente a conclusão de que esses dois últimos é que são os verdadeiros formalistas. Quanto a Schoenberg, o velhinho demonstra estar muito mais vivo e em plena evolução. Porque nele a forma serve a um determinado fim, ao passo que Stravinski, que já escreveu um "Sacre du Printemps", Hindemith que já compôs obras como "Mathis der Malher" acharam um estilo próprio e descansaram (KATUNDA, 1950, p. 7).

Eunice também menciona, no texto direcionado a Santoro, peças de compositores dodecafônicos que, além de impressionar do ponto de vista composicional, também podem causar comoção.

Naturalmente na dodecafonia, como em qualquer outra música, surgem fenômenos complexos de expressões individuais, incompreensíveis as vezes para nós latinos. Li e estudei a sinfonia de Webern. Não compreendi. Mas li e estudei "Augenlicht", do mesmo autor (1935); e essa me causou emoção. Emoção, Santoro. Não só admiração artística/ "Augenlicht" me emocionou, antes mesmo de qualquer análise. Do mesmo modo que me emocionou a Arte da Fuga, de Bach, e uma dansa de S. Gonçalo que assisti há pouco, alí em Ubatuba. Depois da emoção então procurei explicar-me porque aquilo me impressionara tanto, ao passo que a sinfonia só me causara respeito pela maestria da composição, deixando-me fria como criatura humana, instintiva. Creio que foi porque o ambiente musical de "Augenlicht", onde entra a mais intensa forma expressiva da voz humana, me tocou mais de perto; justamente por causa desse conjunto de vozes. (...) Você conhece "Augenlicht"? Mas conhece "Lulu” (1934) e "Wozeck" (1921), as duas óperas de Alban Berg. Como poderá afirmar que essa música não tem conteúdo? Poderá, quando muito dizer que não são músicas socializantes, isto é, músicas escritas com uma intenção definida de propaganda ideológica. Mas as obras de Beethoven também não foram criadas com essa intenção e são o que são. A música, se for sincera e humana, será automaticamente socializante; porque a arte é um fenômeno social e quando deixa de se-lo deixa de ser arte e passa a ser simples elocubração. Os que se perdem no formalismo são os impotentes da música, aqueles que se refugiam nas técnicas e nos absolutismos teóricos para disso fazer um deserto de fórmulas, um deserto de humanidade (KATUNDA, 1950, p. 5-6).

Por fim, no texto de 1950, Eunice também argumenta que a técnica dodecafônica pode ser um recurso para os compositores brasileiros que buscam inserir elementos e expressões musicais nacionais. No entanto, também cita que o resultado disso depende do "elemento humano", ou seja, do compositor.

Talvez a técnica dodecafônica, devidamente utilizada, nos proporcionasse uma saída. Sendo mais neutra e menos elaborada, proporciona maiores probabilidades de se reestruturarem novas formas musicais, mais populares no bom sentido (isto é: mais funcional) onde se vão refletir características mais profundas de expressões musicais nacionais. Tudo depende, naturalmente do elemento humano, já que principalmente as músicas folclóricas resultantes de fusão de tradições negro-europeias revelam, como já disse, algumas características seriais bastante evidentes (KATUNDA, 1950, p. 10) 
Embora Eunice se posicione a favor da corrente estética formalista e da técnica dodecafônica em abril de 1950 em seu texto Problemas musicais contemporâneos, sua postura revela-se totalmente contrária em novembro do mesmo ano, conforme sua carta de apoio à Guarnieri e ao seu posicionamento associado aos ideais do realismo socialista.

\begin{abstract}
Depois de ter passado quase esse mesmo período num isolacionismo voluntário, posso testemunhar como a técnica dodecafônica quanto o formalismo (por mais disfarçado que seja) contribuem para alimentar o derrotismo, a descrença na nossa música e inclusive no nosso povo. Agora que atinjo um verdadeiro período de ressurgimento, de participação, de volta de fato à minha terra e ao meu povo, vejo tudo claro e vejo também que cheguei ao ponto de trabalhar e escrever música com os olhos voltados para a Europa e não para nossa pátria (KATUNDA, 1952 apud KATER, 2020, p. 74).
\end{abstract}

Seguindo esta mesma linha, escreve em 1952 o texto Atonalismo, dodecafonia e música nacional, também publicado pela revista Fundamentos, no qual apresenta argumentos opostos aos pontos defendidos em abril de 1950. Assim, Eunice discute acerca do academicismo e ortodoxia da técnica dodecafônica que, segundo ela, não permitem ao compositor imprimir elementos característicos da música brasileira como o idioma tonal/modal, temas e melodias recorrentes na peça, ritmo, entre outros.

Para escrever-se música nacional dodecafônica ou atonal, seria necessário adotar-se os princípios estéticos e técnicos dodecafônicos, eliminando-se, desde logo, várias coisas indispensáveis à boa expressão musical nacional: a tonalidade, o princípio da repetição, o tema, a melodia (esta frequentemente modal). Teríamos que nos adaptar a uma série quando a música nacional não se fundamenta em séries mas em escalas. A série nos condicionaria às melodias (?) e harmonias (?) implícitas na série. (KATUNDA, 1952 apud KATER, 2020, p. 169)

Por fim, com este rompimento, verifica-se que Quinteto Schoenberg e o texto Problemas musicais contemporâneos foram as últimas manifestações de Eunice enquanto compositora e autora na sua fase denominada Música Viva, ou seja, com ações diretamente ligadas ao dodecafonismo e ao seu criador Arnold Schoenberg.

\title{
Considerações finais
}

A partir da breve análise aqui apresentada sobre o Quinteto Schoenberg, observase que Eunice Katunda buscou homenagear o compositor a partir da aplicação da técnica por ele criada e difundida, assim como pela inserção de hexacordes e mesmo texturas (como o acompanhamento em semicolcheias ininterruptas) presentes em sua obra Ode to Napoleon Buonaparte Op. 41. 
Além disso, observa-se que, da mesma maneira que Schoenberg empregou um poema sobre a técnica dodecafônica em $O p$. 41, Eunice reuniu a técnica dodecafônica com elementos caraterísticos da música folclórica brasileira como, por exemplo, ritmos sincopados, notas repetidas e melodias modais. Dessa maneira, deu a seu Quinteto Schoenberg características musicais próprias e não ortodoxas, inserindo no mesmo um caráter humanista, conforme também entendia as obras de seu admirado e homenageado compositor.

A compreensão da compositora acerca da linguagem musical contemporânea do final da década de 1940 é mais um traço de sua personalidade curiosa, obstinada pelo conhecimento e comprometida com a busca pelo novo com seriedade e profundidade.

No entanto, sendo um ser político como foi observado por Iddon (2013) em citação anterior, a compositora não poderia deixar de se posicionar contra tudo isso e ao lado do que na época lhe pareceu mais urgente, ou seja, um realinhamento estético em favor do nacionalismo musical.

\section{Referências}

ANDRADE, Mario de. Ensaio sobre a música brasileira. 3 ed. São Paulo: Livraria Martins Editora S.A., 1972.

IDDON, Martin. New Music at Darmstadt: Nono, Stockhausen, Cage, and Boulez. Cambridge: Cambridge University Press, 2013.

KATER, Carlos. Eunice Katunda: musicista brasileira. São Paulo: Annablume, 2001.

KATER, Carlos. Música Viva e H.- J. Koellreutter: movimentos em direção à modernidade. São Paulo: Musa, 2001b.

KATER, Carlos. Eunice Katunda: musicista brasileira / brazilian musician. 2 ed. São Paulo: $\mathrm{M} \& \mathrm{~K}, 2020$.

KATUNDA, Eunice. Problemas musicais contemporâneos. 1950. Manuscrito.

KATUNDA, Eunice. Álbum de recortes de jornais. Acervo particular, c.1925-c.1970.

PEIXOTO, Melina de Lima. A obra para canto e piano de Eunice Katunda: três momentos. Dissertação (Mestrado em Música). Belo Horizonte: Universidade Federal de Minas Gerais, 2009.

RIZZARDI, Veniero. La "Nuova Scuola Veneziana" 1948-1951. In: OLSCHKI, Leo S. Le musiche degli anni cinquanta. Venezia: Fondazione Giorgio Cini, 2004. 
SHAW, Jennifer; AUNER, Joseph. The Cambridge Companion to Schoenberg. Cambridge: Cambridge University Press, 2010.

STRAUS, Joseph N. Introduction to Post-tonal Theory. 3 ed.. New Jersey: Pearson Education, Inc., 2005.

VASCONCELOS, Rodrigo de Carvalho. Coleções referenciais do Mikrokosmos de Bartók e da Prole do Bebê n. 1 de Villa-Lobos. Dissertação (Mestrado em Música). São Paulo: Universidade de São Paulo, 2014.

ZANI, Amilcar; SILVA, Eliana Monteiro; CANDIDO, Marisa Milan. A composição de Eunice Katunda no contexto político e musical brasileiro. In: Extraprensa, v. 12, n. 2, jan./jun., 2019. 